\title{
O PROCESSO DE FORMAÇÃO, ESPECIALIZAÇÃO E PROFISSIONALIZAÇÁO DO ILUSTRADO MANUEL FERREIRA DA CÂMARA (1783-1800)
}

\author{
Alex Gonçalves Varela \\ Historiador, Bolsista PCI de Pós-Doutorado do MAST-MCT-RJ
}

\begin{abstract}
Resumo
O personagem Manuel Ferreira da Câmara ficou conhecido pelo seu perfil político de estadista e parlamentar, sobretudo por sua atuação no período da Independência. Sua trajetória histórica, contudo, caracteriza-se pela associação entre os interesses políticos e a face de estudioso das ciências naturais. $\mathrm{O}$ objetivo deste trabalho consiste em analisar o processo de formação, especialização e profissionalização do personagem no contexto da política estatal de renovação cultural-científica do governo de Dona Maria I.
\end{abstract}

\section{Pallavras-Chave}

História das Ciências • Manuel Ferreira da Câmara • Universidade de Coimbra

-Academia Real das Ciências de Lisboa • Ilustração luso-americana.

\section{Abstract}

Manuel Ferreira da Câmara is known to his profile of Statesman and Parliamentary, above all his political performance in the Independence period. His historical trajectory, however, characterize by the association between the political interests and the natural sciences studious profile. The objective of this paper is to analyze the process of formation, specialization and professionalization of the Enlightened, in the context of the estate policy cultural-scientific renovation from the D. Maria I government.

\section{Keywords}

History of Sciences • Manuel Ferreira da Câmara • Coimbra University • Lisbon Royal Academy of Science $\bullet$ Luso-american Enlightenment. 
A presença do ilustrado Manuel Ferreira da Câmara Bethencourt Aguiar e Sá na bibliografia especializada se dá em função do seu perfil de político, evidenciando a sua atuação enquanto estadista e parlamentar. Tais análises dão relevância à atuação do personagem no período da Independência, e quando atuou como deputado na Assembléia Nacional Constituinte de 1823, e como senador por Minas Gerais no período de 1827 a 1835. Um exemplo desse tipo de enfoque que enfatiza exclusivamente o viés político de sua trajetória histórica é o artigo curto de J. F. Sigaud. ${ }^{1}$

No entanto, Manuel Ferreira da Câmara notabilizou-se não apenas como homem público mas também como um estudioso e pesquisador do mundo natural. Em sua trajetória histórica, a face de naturalista e os interesses políticos são indissociáveis, fato que caracteriza o homem ilustrado do século XVIII. ${ }^{2}$ Não são duas carreiras diferentes ou sucessivas, mas dois perfis de uma mesma trajetória de vida que não podem ser de forma alguma cindidos: o de estudioso das ciências naturais e o de homem público. Portanto, há lacunas que estimulam a reflexão sobre o personagem em novas direções.

O que também se pode observar, após um levantamento preliminar, é a existência de pouca bibliografia sobre a trajetória de vida desse personagem, em que ganham destaque a biografia de Marcos Carneiro de Mendonça ${ }^{3}$ e alguns artigos curtos, como os de O. H. Leonardos ${ }^{4}$ e V. Leinz. ${ }^{5}$ Somente nos últimos

\footnotetext{
${ }^{1}$ Como exemplo dessa historiografia que destaca o perfil político de Manuel Ferreira da Câmara ver SIGAUD, J. F. “Dr. Manoel Ferreira da Câmara de Bittancourt e Sá”. Revista do Instituto Histórico e Geográfico Brasileiro. Rio de Janeiro, tomo IV, p.515-8, 1842.

${ }^{2}$ A associação entre interesses científicos e políticos é bastante clara na trajetória histórica dos homens da Ilustração. Como exemplo, mencionamos o francês Antoine Laurent Lavoisier (1743-1794) que atuava ao mesmo tempo como químico e Ferme Générale, coletor de impostos do Antigo Regime francês. Ver BENSAUDE-VINCENT, Bernardette. "Lavoisier: uma Revolução Científica”. In: SERRES, Michel (Dir.). Elementos Para uma História das Ciências. Lisboa: Terramar, 1996.

${ }^{3}$ MENDONÇA, Marcos Carneiro. O Intendente Câmara. Manuel Ferreira da Câmara Bethencourt e Sá, Intendente Geral das Minas e dos Diamantes, 1764-1835. São Paulo: Companhia Editora Nacional, 1958.

${ }^{4}$ LEONARDOS, O. H. “O Intendente Câmara”. Engenharia, Mineração e Metalurgia. Rio de Janeiro, v.36, n.215, 1962, p. 226-228.

${ }^{5}$ LEINZ, V. "Manoel Ferreira da Câmara e José Bonifácio de Andrada e Silva Ingressando na escola de Minas de Freiberg". Engenharia, Mineração e Metalurgia. Rio de Janeiro, v.38, n.227, 1963, p. 213-215.
} 
anos, em razão do resgate da história das ciências na América Latina sob novo arcabouço historiográfico, é que Câmara voltou a ser objeto de estudo, destacando-se os trabalhos de Manuel Serrano Pinto ${ }^{6}$ e Silvia Figueirôa. ${ }^{7}$

Contudo, falta ainda um estudo contextualizado da vida e obra do naturalista inserido no debate mais amplo sobre a história e a historiografia das ciências no Império Português, reconhecendo-se o peso do reformismo Ilustrado e os variados papéis profissionais que desempenhou. Como argumentou Silvia Figueirôa, ${ }^{8}$ a supremacia da história política e administrativa, aliada às concepções historiográficas sobre a carência de atividades científicas locais levou, de forma conjunta, à falta de um lugar na história e ao tratamento de exceção para o que foi efetivamente realizado no campo científico, alimentando um círculo gerador de homens excepcionais e de seus contemporâneos pouco lembrados.

Neste trabalho temos como objetivo analisar o processo de formação, especialização e profissionalização do ilustrado, dentro da política estatal de renovação cultural-científica do governo mariano, com o intuito de criar um novo corpo de funcionários ilustrados para fornecer pessoal à burocracia estatal e formar uma "elite do conhecimento" interessada na exploração do mundo natural do Reino e das colônias. Quatro momentos desse processo serão destacados: os estudos na Faculdade de Filosofia da Universidade de Coimbra; a entrada para a Academia Real das Ciências de Lisboa; a viagem científica pelos principais centros de mineração da Europa Central e Setentrional; e, a indicação para cargo de Consultor do Governo em Assuntos de Minas.

\section{I - A Formação em Leis e Filosofia Natural na Universidade de Coimbra}

Manuel Ferreira da Câmara Bethencourt Aguiar e Sá, filho de Francisca Antônia Xavier de Bethencourt e Sá e do tenente Bernardino Rodrigues

\footnotetext{
${ }^{6}$ PINTO, Manuel Serrano. "A experiência européia de Manoel Ferreira da Câmara e seus reflexos no Brasil - algumas notas”. In: FIGUEIRÔA, S. F. de M. \& LOPES, M. M. (orgs.). Geological Sciences in Latin America. Scientifics relations and exchanges. Campinas, SP: UNICAMP/IG, 1994, pp. 245-264.

${ }^{7}$ FIGUEIRÔA, Silvia F. de M. 'Um 'Pensionário Fiel de Sua Majestade': Manuel Ferreira da Câmara, 1764-1835". In: ARANGO, Diana Soto et al. (Orgs.). Científicos Criollos e Ilustración. Madrid: Ediciones Doce Calles; Colciencias; Rudecolombia, 1999.

${ }^{8}$ Ibidem, p. 214.
} 
Cardoso, nasceu em Minas Gerais, muito provavelmente em Santo Antônio de Itacambira, em territórios da Demarcação Diamantina, por volta de 1764.

A família de Câmara possuía status social elevado. Seu pai era tenente, e sua mãe provinha de uma família de muitas posses, com fortuna ligada às minas de ouro. Dois dos seus tios maternos haviam-se formado em Coimbra, em Cânones, tendo um deles chegado a desembargador. ${ }^{9}$ Após a mudança dos pais da região de Minas Gerais para a Bahia, ele e o irmão, José de Sá Bethencourt e Accioli, ${ }^{10}$ foram educados por uma tia - proprietária de minas de ouro - em Caeté, Minas Gerais, região aurífera até a atualidade.

Como todos os membros da elite colonial que desejavam realizar um curso superior, uma vez que na América Portuguesa não havia instituições universitárias, Câmara viajou para a metrópole com o intuito de se matricular na Universidade de Coimbra. A sua chegada a Portugal coincidiu com o período de "abertura" às novas idéias em razão das iniciativas do Marquês de Pombal.

Câmara matriculou-se em Coimbra no ano de 1783 nos curso de Leis. No ano seguinte, passou a cursar também o de Filosofia Natural. Tornou-se bacharel em Leis e Filosofia no ano de 1787 e obteve o diploma em junho de $1788 .{ }^{11}$ Nesse período, juntou-se às elites cultas da metrópole que também ali estudavam; todos leram as mesmas obras e receberam a mesma formação. ${ }^{12}$

\footnotetext{
${ }^{9}$ O status social elevado da família de Câmara permite estabelecer uma comparação com o estudioso José Bonifácio de Andrada e Silva, cujo pai possuía uma das maiores fortunas de Santos. Ver: VARELA, Alex Gonçalves. “Juro-lhe Pela Honra de Bom Vassalo e Bom Português": Análise das Memórias Científicas de José Bonifácio de Andrada e Silva (1780-1819). São Paulo: Annablume, 2006. 270p.

${ }^{10}$ Sobre José de Sá Bethencourt e Accioli ver o trabalho de: SILVA, Clarete Paranhos da. Garimpando Memórias: as ciências Mineralógicas e Geológicas no Brasil na Transição do Século XVIII para o XIX. Tese (Doutorado em Ciências da Terra). Universidade Estadual de Campinas, Campinas, 2004.

${ }^{11}$ No período de 1772-1822, 866 "portugueses naturais do Brasil” se formaram em Coimbra, cerca da metade deles em Leis e Matemática ou Ciências Naturais, acumulando as duas ou três especialidades. Ver: MORAIS, Francisco de. "Lista dos estudantes brasileiros na Universidade de Coimbra”. Anais da Biblioteca Nacional. Rio de Janeiro, v.62, p. 141. Vale salientar ainda que Câmara compunha a elite da Capitania de Minas Gerais que foi titulada por Coimbra e que seria arregimentada no serviço do Estado no período mencionado. BOSCHI, Caio C. "A Universidade de Coimbra e a Formação Intelectual das Elites Mineiras Coloniais". Estudos Históricos. Rio de Janeiro, vol.4, n.7, p.100-111, 1991.
} 
O estudioso ingressou na Faculdade de Filosofia - criada no conjunto das reformas pombalinas com o objetivo de ensinar ciências naturais e ciências físicoquímicas -, cujo curso regular tinha duração de quatro anos. Não havia qualquer curso preparatório, e no ensino sobressaíam os compêndios de Antonio Genovese, Carl von Linné, Petrus von Musschenbroek e a História natural de Plínio.

Durante o período em que esteve na universidade, Câmara recebeu uma ampla formação. Na Faculdade de Direito cursou as cadeiras de português, direito natural, história do direito civil romano, elementos de direito romano, elementos de direito canônico, direito civil pátrio e jurisprudência. Na Faculdade de Filosofia, cursou as cadeiras de história natural, física experimental, química teórica e prática. E na Faculdade de Matemática freqüentou o curso de geometria.

As aulas na reformada Universidade de Coimbra, sobretudo no curso de Filosofia, onde lecionavam homens como Domenico Vandelli, funcionaram como um pólo de divulgação do novo conceito de ciência - uma ciência vocacionada para a aplicação prática e para o progresso das atividades econômicas, cujo objetivo último era a criação das condições necessárias para o bem-estar e para a felicidade dos povos. Essa nova visão da ciência influenciou as gerações que entre o final do século XVIII e os inícios do século XIX passaram por essa instituição. ${ }^{13}$

Foi no espaço universitário que Câmara teve os seus primeiros contatos com aquele que seria o seu principal interlocutor, o naturalista José Bonifácio de Andrada e Silva. Os dois tiveram formação e trajetória de vida muito parecidas. Após o término dos estudos em Coimbra, foram aliciados pela política portuguesa que visava privilegiar as carreiras públicas de indivíduos nascidos na América. ${ }^{14}$ Tal fato demonstra o papel central da Universidade como locus

\footnotetext{
${ }^{12}$ José Bonifácio e Câmara comporiam, no período da Independência, aquilo que Lúcia Neves chamou de "elite coimbrã", a facção mais conservadora da elite luso-americana, que partilhava da idéia de um grande Império luso-americano, característico da geração de 1790, da qual faziam parte. NEVES, Lúcia Maria Bastos Pereira das \& MACHADO, Humberto Fernandes. O Império do Brasil. Rio de Janeiro: Nova Fronteira, 1999. 502 p. Ver também: MAXWELL, Kenneth. "A geração de 1790 e a idéia do Império luso-americano". In: MAXWELL, Kenneth. Chocolate, piratas e outros malandros. Ensaios tropicais. Rio de Janeiro: Paz e Terra, 1999; SILVA, Maria Beatriz Nizza da. A cultura luso-brasileira: da reforma da universidade à Independência do Brasil. Lisboa: Editorial Estampa, 1999.

${ }^{13}$ MATOS, Ana Maria Cardoso de. Ciência, Tecnologia e Desenvolvimento Industrial no Portugal Oitocentista. O Caso dos Lanifícios do Alentejo. Lisboa: Editorial Estampa, 1998.
} 
de preparação e de treinamento de uma elite luso-americana, modernizadora e ilustrada, que se colocaria a favor de uma política de Estado, cujo objetivo era regenerar o Império Português. ${ }^{15}$

\section{II- A Entrada Para a Academia Real das Ciências de Lisboa}

Após a conclusão do curso superior em Coimbra, Câmara permaneceu em Portugal, sendo eleito membro da Academia Real das Ciências de Lisboa no ano de 1789. A Academia foi um centro aglutinador do ideário reformista do governo de D. Maria $\mathrm{I}^{16}$ e um locus de debate científico e da gestão da política colonial voltada para a exploração do mundo natural. ${ }^{17}$ Neste espaço, Câmara integrou-se ao sub-grupo de naturalistas, ${ }^{18}$ que tinha como personagem principal o italiano Domenico Vandelli. ${ }^{19}$

Vandelli defendia a realização de um profundo inventário da natureza do Reino e das colônias, que seria estudada nos estabelecimentos científicos lisboetas, como os Jardins Botânicos e Museus de História Natural, entre outros, por meio dos métodos de classificação e dissecação. Ele teve uma atuação fun-

\footnotetext{
${ }^{14}$ KANTOR, Iris. "Ciência e Império: Trajetórias de Ilustrados Lusoamericanos na Segunda Metade do Século XVIII". In: Laboratório do Mundo. Idéias e Saberes do Século XVIII. São Paulo: Pinacoteca; Imprensa Oficial, 2004, p. 248.

${ }^{15}$ BOSCHI, op. cit., p.108; SILVA, Ana Rosa Cloclet. A Formação do Homem-Público no Portugal Setecentista: 1750-1777. Revista Intellectus. Rio de Janeiro, ano 2, vol.2, 2003, p. 27.

${ }^{16} \mathrm{O}$ ápice da Ilustração portuguesa ocorreu no momento em que D. Maria I assumiu o trono, dando início ao que se convencionou chamar de "viradeira". Esse período caracterizou-se pelo reforço das práticas Ilustradas de caráter pragmático-científico, que já vinham sendo fomentadas desde o período do consulado pombalino, durante o reinado anterior de D. José I. Ver: NOVAIS, Fernando. Portugal e Brasil na Crise do Antigo Sistema Colonial (1777-1808). $6^{\mathrm{a}}$ ed. São Paulo: HUCITEC, 1995; FALCON, Francisco José Calazans. A Época Pombalina. Política Econômica e Monarquia Ilustrada. $2^{\text {a }}$ Ed. São Paulo: Editora Ática, 1993.

${ }^{17}$ MUNTEAL FILHO, Oswaldo. Uma sinfonia para o novo mundo: a Academia Real das Ciências de Lisboa e os caminhos da Ilustração luso-brasileira na crise do antigo sistema colonial. Tese de doutorado. Departamento de História, UFRJ, Rio de Janeiro, 1998.

${ }^{18}$ MUNTEAL FILHO, Oswaldo. Domenico Vandelli no anfiteatro da natureza: a cultura científica do reformismo ilustrado português na crise do antigo sistema colonial (1779-1808). Dissertação de mestrado. Departamento de História, PUC-Rio, Rio de Janeiro, 1993.

${ }^{19} \mathrm{O}$ paduano Domenico Vandelli, no âmbito da Academia, adotou o ecletismo do reformismo Ilustrado, pelo qual se posicionou em favor de algumas idéias do mercantilismo, adotando tanto os princípios fisiocráticos italianos e franceses como os princípios da economia clássica inglesa. NOVAIS, Fernando A. "O reformismo ilustrado luso-brasileiro: alguns aspectos”. Revista Brasileira de História. São Paulo, n.7, 1984.
} 
damental para a criação do "complexo museológico da Ajuda", ${ }^{20}$ que centralizava o vasto projeto de se produzir uma 'história natural do Reino e das colônias'.

$\mathrm{O}$ conhecimento da natureza estava diretamente relacionado à política fomentista do governo mariano e joanino, uma vez que se acreditava que as produções naturais da colônia ajudariam na recuperação econômica do Reino e valorizava-se a agricultura, baseada nas práticas científicas de orientação pragmática, que via na natureza tropical uma fonte geradora de riqueza. A natureza americana, portanto, deveria ser cientificamente conhecida e explorada, pois contribuiria para o processo de industrialização português.

Na Academia, Câmara publicou diversas memórias científicas. A primeira dissertação, apresentada a 13 de maio de 1789, intitula-se Ensaio de Descrição Física e Econômica da Comarca de Ilhéus na América. O estudo divide-se em três partes e, logo na sua introdução, Câmara destaca o caráter útil do seu trabalho, e, portanto, moderno: "O desejo de ser útil à minha nação me faz ser atrevido, e dar-me-ei por muito feliz se das minhas tais quais observações puder resultar algum bem à pátria, ou à humanidade". ${ }^{21}$

O pragmatismo e o utilitarismo são duas características presentes na prática científica do naturalista Manuel Ferreira da Câmara, como de outros estudiosos luso-americanos. ${ }^{22}$ Contudo, tais atributos não foram exclusivos da Ilustração lusoamericana. As ciências naturais modernas de perfil baconiano, em sua essência, pressupunham a utilidade e o bem-estar dos homens. Para Bacon, a história natural era uma forma de investigação destinada a registrar o conhecimento do mundo para o uso e o aperfeiçoamento da humanidade. E será na direção da procura da utilidade que o estudo da natureza convergirá no século XVIII, firmando-se assim

\footnotetext{
${ }^{20}$ BRIGOLA, João Carlos Pires. Coleções, Gabinetes e Museus em Portugal no século XVIII. Lisboa: Fundação Calouste Gulbenkian: Fundação para a Ciência e a Tecnologia : Ministério da Ciência e do Ensino Superior, 2003.

${ }^{21}$ CÂMARA, Manuel Ferreira da. "Ensaio de Descrição Física, e Econômica da Comarca dos Ilhéus na América (1789)". In: Memórias Econômicas da Academia Real das Ciências de Lisboa, Para o Adiantamento da Agricultura, das Artes, e da Indústria em Portugal, e Suas Conquistas (1789-1815). Tomo I. Lisboa: Banco de Portugal, 1990, p.229.

${ }^{22} \mathrm{O}$ historiador Ronald Raminelli considerou que o naturalista Alexandre Rodrigues Ferreira não estava conectado aos avanços da ciência no século XVIII porque suas memórias científicas continham dados utilitários. O autor deixou assim transparecer a falta de conhecimento sobre a prática da História Natural no setecentos. O utilitarismo era uma característica central da História Natural nesse momento. RAMINELLI, Ronald. "Ciência e Colonização - Viagem Filosófica de Alexandre Rodrigues Ferreira”. Tempo. Rio de Janeiro, v. 3, n. 6, p. 164, dezembro de 1998.
} 
como a crítica do conhecimento diletante. Novos museus, jardins botânicos, academias científicas e coleções tomaram o lugar dos gabinetes de curiosidades e dos jardins consagrados exclusivamente ao deleite aristocrático. A História Natural que se estabeleceu nas instituições européias, por exemplo, nas francesas da última década do século XVIII, era marcada por forte utilitarismo. ${ }^{23}$

Seguindo as considerações da historiadora das ciências Maria Margaret Lopes, ${ }^{24}$ vários trabalhos sobre o tema da Ilustração luso-americana do Setecentos têm sido produzidos sob um enfoque que prioriza as conotações políticoeconômicas do processo, deixando de lado a produção cultural-científica do período, não incorporando os entendimentos de ciências efetivamente veiculados e postos em prática para alicerçar os processos modernizadores de Portugal e do Ultramar. Na maioria dos casos, seguindo as considerações da mencionada historiadora das ciências, reduz-se todo o movimento do Império português de adesão às ciências modernas a apenas "utilitarismos", "pragmatismos", "imediatismos", de conotações pejorativas. Ademais, reforçam-se visões que partilham as noções de "atraso" científico português, e conseqüentemente brasileiro, e sua inviabilidade de participação nas ciências européias do período.

Ainda analisando a citação de Câmara, observa-se que o termo nação traduz o pertencimento à monarquia portuguesa, revelando o grau de envolvimento de Câmara na execução do programa político-reformista do governo mariano. ${ }^{25}$

\footnotetext{
${ }^{23}$ KURY, Lorelai Brilhante. Entre Utopia e Pragmatismo: a História Natural no Iluminismo Tardio. In: SOARES, Luiz Carlos. (Org.) Da Revolução Científica à Big (Business) Science. São Paulo: HUCITEC; Rio de Janeiro: EDUFF, 2001, pp. 142-143.

${ }^{24}$ LOPES, Maria Margaret; FIGUEIRÔA, Silvia F. de Mendonça. Relatório científico final do projeto emergência e consolidação das ciências naturais no Brasil (1770-1870). Campinas: DGAE/IGE/Unicamp, 2003, mimeografia, p. 50.

${ }^{25}$ A idéia de nação como o sentimento de pertencimento à Monarquia Portuguesa aparecia em textos de outros ilustrados reformistas nascidos na colônia e agentes ativos na execução da política de edificação do Império luso-brasileiro. Afinal, no sistema então vigente não havia dúvidas quanto ao pertencimento de todos os "nascidos nas quatro partes do mundo português" à Monarquia lusa, nem tampouco se podia negar que todos eram descendentes do povo português emigrado para o Brasil. Sobre tal discussão ver: LYRA, Maria de Lourdes Viana. A Utopia do Poderoso Império: Portugal e Brasil: Bastidores da Política, 1798-1822. Rio de Janeiro: Sette Letras, 1994; LYRA, Maria de Lourdes. "Pátria do cidadão": A concepção de pátria/nação em Frei Caneca. Revista Brasileira de História. São Paulo, vol.18, n.36, 1998; NEVES, Guilherme Pereira das. Do Império Luso-Brasileiro ao Império do Brasil (17891822). Ler História. Lisboa, v.27/28, 1995, p. 75-102; SILVA, Ana Rosa Cloclet da. Construção da Nação e Escravidão no Pensamento de José Bonifácio, 1783-1823. São Paulo: FAPESP; Campinas: Editora da UNICAMP, 1999.
} 
No ano de 1797 ou 1798, o ministro da Marinha e Ultramar, Dom Rodrigo de Sousa Coutinho, apresentou a Memória Sobre o Melhoramento dos Domínios de Sua Majestade na América, lançando assim o "programa de reformas" cujo objetivo principal era a regeneração do Império Português. No programa, Portugal passava a ser concebido como o centro das decisões políticas e das relações comerciais, enquanto os domínios no ultramar passariam a constituir "províncias da Monarquia", reunidas todas num "mesmo sistema administrativo" e "sujeitas aos mesmos usos e costumes". O objetivo fundamental era o resguardo do "sacrossanto princípio da unidade, primeira base da Monarquia que se deve conservar com o maior ciúme a fim de que o português nascido nas quatro partes do mundo português se julgue somente português e não se lembre senão da glória e grandeza da Monarquia, a que tem a fortuna de pertencer". ${ }^{26} \mathrm{O}$ Estado monárquico imperial aparecia como o elemento unificador das partes distintas e dispersas do mundo português, e o sentimento de pertencimento à nação lusa, então explicitamente evocado, exerceria também a função asseguradora da unidade do território português na América, até então reconhecido sob o "genérico nome de Brasil". ${ }^{27}$

Retornando à análise da Memória de Câmara, na primeira parte, intitulada "Estrutura física" da Comarca de Ilhéus, há informações sobre a situação geográfica, os limites, extensão da superfície, configuração do terreno, o ar em geral, os rios, as vilas e as matas, entre outras. Nessa parte do texto, a localização do rios e baías foi o objeto que mais recebeu atenção, revelando assim um naturalista pragmático em sua procura por boas enseadas e portos para a entrada e saída de embarcações. Certamente a facilitação do comércio constituía uma preocupação do autor, como ficou claro em sua argumentação sobre a importância da barra de Camamu: "Por meio desta excelente barra se pode fazer um comércio direto com o Reino, e exportar tudo quanto este vasto continente pode produzir, independentemente de qualquer outro porto marítimo do Brasil". ${ }^{28}$

\footnotetext{
${ }^{26}$ Apud LYRA, Maria de Lourdes Viana. op. cit., p. 87.

${ }^{27}$ No momento da crise final do sistema colonial, não havia um território brasileiro unificado no plano político. Havia, na feliz expressão de Demétrio Magnoli, "blocos de colônias" vinculados diretamente à metrópole pela administração das capitanias hereditárias, configurando elementos de um todo que era o Império Português. MAGNOLI, Demétrio. "O Estado em Busca do seu Território”. In: JANCSÓ, István (org.). Brasil: a Formação do Estado e da Nação. São Paulo: FAPESP; Editora HUCITEC, 2004, p. 294.

${ }^{28}$ CÂMARA, Manuel Ferreira da. "Ensaio de Descrição Física, e Econômica da Comarca dos Ilhéus na América (1789)”, op. cit., p. 260.
} 
Na segunda parte da Memória, intitulada "Do estado atual da sua agricultura, e do seu comércio", Câmara argumentou que os habitantes de Ilhéus só cultivavam e comercializavam a mandioca e o arroz, e não empreendiam novos ramos de lavoura. Para ele, era necessário diversificar a produção agrícola local com novos cultivos, como as uvas, o cacau, o tabaco, o açúcar, entre outros, e tentar aclimatar na região "uma grande parte dos frutos da Europa, que vulgarmente se encontram em todo o Brasil" como a maçã, o marmelo, o pêssego e as ameixas, e outros. E, também "grande parte dos legumes e plantas" de que se alimentam os habitantes europeus.

A terceira parte do estudo foi dividida em três itens. No primeiro, o autor argumentou sobre a necessidade de uma "reforma da agricultura" na Comarca de Ilhéus. Apontou os gêneros agrícolas que eram cultivados na Comarca, como o cacau, e aqueles que deveriam ser transplantados, como a canela, o cravo do Maranhão, a salsaparrilha, a contra-erva, a ipecacuanha, o café, o açafrão, o anil, o tamarindo, o algodão e a cana-de-açúcar, entre outros, sempre mencionando a sua importância e utilização econômica.

A afirmação da agricultura como a principal fonte de riqueza é um tema muito presente nos estudos dos naturalistas luso-americanos do período abordado aqui. Domingos Vandelli, por exemplo, colocava a agricultura entre suas primeiras preocupações. O professor italiano publicou diversas memórias na Academia Real das Ciências de Lisboa tratando da agricultura e da sua importância para o desenvolvimento do Reino. No conjunto de publicações da Academia, a agricultura é um dos assuntos que mais aparece. ${ }^{29}$

A agricultura, sem dúvida, dominava as atenções dos naturalistas da Academia. Contudo, devemos estar atentos para o fato de que essa preocupação prevalecente com a agricultura não significava uma adesão sistemática à fisiocracia. De acordo com Vera Ferlini, o pensamento fisiocrático era mobilizado para servir a uma política reformista. ${ }^{30}$ Embora a preocupação com a agricultura fosse

\footnotetext{
${ }^{29}$ MUNTEAL FILHO, op. cit.

${ }^{30}$ Vera Ferlini argumentou que as proposições dos sócios da Academia referentes à agricultura não assumiam uma postura revolucionária, mas reformista. Os acadêmicos não questionavam em momento algum a estrutura agrária do Antigo regime português, nem atacavam a propriedade e as relações de produção vinculadas estritamente aos privilégios estamentais do clero e da aristocracia. FERLINI, Vera Lúcia Amaral. "A Questão Agrária no Pensamento Reformista Luso-Brasileiro do Século XVIII: Estrutura Fundiária, Legislação Territorial e Proposta de Mudanças". In: BICALHO, Maria Fernanda et al. (org.) Modos de Governar. Idéias e Práticas Políticas no Império Português. Séculos XVI a XIX. São Paulo: Alameda, 2005, p. 299.
} 
preponderante nas memórias dos vários sócios, muitos deles tendiam para um ecletismo, caracterizando a postura metodológica dos Ilustrados portugueses. ${ }^{31}$

O segundo item da terceira parte da Memória teve como tema a importância das pescas que se realizavam na costa da Comarca de Ilhéus. Segundo Câmara, a pesca deveria ser vista como um ramo de riqueza e de comércio exterior, uma vez que poderia gerar "produtos úteis às artes, e aos usos econômicos", como a pesca das baleias e a extração do seu azeite. Contudo, o autor afirmou que a pesca das baleias em Ilhéus estava sujeita a infinitos erros, precisando urgentemente de uma "reforma", que tornaria tal atividade altamente lucrativa ao Estado.

O terceiro item teve como tema a "Cultura, conservação e corte das madeiras". Câmara discorreu sobre a importância das matas para Portugal e para o Brasil, sobretudo no que diz respeito "à construção, e à combustão diária". Contudo, os habitantes estavam destruindo tais produções vegetais, de tal forma que estavam faltando todas as "espécies de preciosas madeiras", e, com o tempo, este se tornaria um "gênero mui caro". O naturalista então apontou a necessidade de o Estado controlar a exploração irregular das matas por meio da nomeação de ministros que "vigiem, e regulem o corte das madeiras em geral e indistintamente" e obrigar os habitantes a se preocuparem com a reprodução de tais espécies vegetais.

A preocupação de Câmara com a conservação das matas reside no fato dessas produções vegetais serem fontes importantes de madeiras para a construção das casas como também para a construção de navios. Lembremos também que sendo o autor um "metalurgista de profissão", ele tinha uma profunda consciência a respeito da exploração racional das árvores, pois estas eram fontes de abastecimento energético das siderúrgicas e dos engenhos, uma vez que o carvão, fonte de combustível com o advento da revolução industrial inglesa, não existia em quantidade suficiente em Portugal e no Brasil. A falta de lenhas, de madeiras e de carvão paralisaria a produção "das ferrarias e com o aumento progressivo de mais fornos e forjas, como convém, nem estabelecerem-se para o futuro fábricas de aço, espingardas, cutelaria e outras oficinas úteis, de que muito precisam os meus Reinos [do Rei de Portugal]". ${ }^{32}$

\footnotetext{
${ }^{31}$ NOVAES, op. cit.

${ }^{32}$ VARELA, op. cit., p. 179.
} 
Lembremos que a madeira era considerada, antes do surgimento da revolução industrial, a principal fonte de combustível. ${ }^{33} \mathrm{~A}$ descoberta do carvão mineral como elemento capaz de servir como combustível para a indústria siderúrgica na produção de ferro, sobretudo para o seu refino e fundição, pôs fim à "era da madeira" enquanto principal material de construção e combustível da civilização. O carvão passou a ser a principal fonte de energia industrial do século XIX, mas também um importante combustível doméstico. ${ }^{34}$

Daí a argumentação de Câmara em prol da conservação das matas e bosques. Portugal, e a sua principal possessão colonial, o Brasil, não tinham depósitos de carvão mineral. Por sua vez, a diminuição de tais recursos naturais aumentaria a dependência de Portugal com relação à Inglaterra, sobretudo com os gastos relacionados à importação de carvão. A solução para tal questão era continuar a utilizar a madeira como fonte de combustível. Em função disso, a exploração irracional das matas e bosques deveria ser freada e o Estado português passaria a ser o agente único e exclusivo de utilização e exploração racional dessas produções vegetais.

Portanto, nas reflexões de Câmara, a conservação das produções vegetais está intimamente associada aos interesses econômicos do Estado português, uma vez que se temia a eliminação de um recurso natural cujo uso era útil e rentável. O que estava em questão era a economia ameaçada pela escassez das matas e bosques, e não o ambiente em si mesmo, o motivo das preocupações. ${ }^{35}$

A segunda dissertação apresentada no ano de 1789, em agosto, intitula-se Memória de Observações Físico-Econômicas Acerca da Extração do Ouro do Brasil.

\footnotetext{
${ }^{33}$ De acordo com John Perlin, os esteios de madeira suportavam os poços das minas para a extração do carvão mineral. Em seguida, o carvão era embarcado em carretas de madeira para as fábricas siderúrgicas, sobre trilhos de madeira ou em navios de madeira por canais cujas comportas também eram de madeira. Posteriormente, a madeira foi substituída por ferro. PERLIN, John. História das Florestas: a Importância da Madeira no Desenvolvimento da Civilização. Rio de Janeiro: Imago, 1992.

${ }^{34}$ HOBSBAWM, Eric. A Era das Revoluções. Rio de Janeiro: Paz e Terra, 1987.

${ }^{35}$ Sobre o conservacionismo nas memórias científicas dos ilustrados luso-americanos setecentistas ver: PRESTES, Maria Elice Brzezinski. A Investigação da Natureza no Brasil Colônia. São Paulo: Annablume; FAPESP, 2000. Ao considerarmos que não há nas reflexões de Câmara qualquer vestígio de uma mentalidade pró-conservação no sentido que o século XX o entende assumimos uma perspectiva interpretativa diferente em relação a análise do historiador PÁDUA, José Augusto. A Degradação do Berço Esplêndido: Pensamento Político e Crítica Ambiental no Brasil Escravista, 1786-1888. Rio de Janeiro: Jorge Zahar Editora, 2002.
} 
Logo no início do estudo, na parte introdutória, Câmara deixou transparecer a importância que conferia à mineração, em especial à exploração do ouro. Mostrou também o seu esforço em estudar outros campos do conhecimento científico, como a física e a química, para assim aplicá-los à prática de extrair o referido metal.

Esse estudo de Câmara está inserido em um vasto acervo de memórias, artigos e discursos elaborados entre o final do século XVIII e o início do XIX em torno da recuperação do setor de produção mineral no Brasil, nomeadamente a de ouro. Dentre esses escritos destacamos dois exemplos: o Discurso Sobre o Estado Atual das Minas do Brasil, do bispo José Joaquim da Cunha Azeredo Coutinho, e publicado em 1804 pela Imprensa Régia, em Lisboa, que considerava a mineração a razão da decadência de Portugal; e o Discurso Sobre a Verdadeira Influência das Minas dos Metais Preciosos na Indústria das Nações que as Possuem, e Especialmente da Portuguesa, escrito por D. Rodrigo de Sousa Coutinho, publicado pela Academia Real das Ciências de Lisboa, tomo I das Memórias Econômicas (1789-1815), que afirmava a importância da mineração enquanto atividade geradora de riquezas para a nação portuguesa.

No âmbito desse debate dos que se colocavam a favor ou contra a mineração, ${ }^{36}$ o texto de Câmara se destaca por se alinhar aos defensores da recuperação da mineração para o desenvolvimento econômico da nação portuguesa, como D. Rodrigo, José Bonifácio e José Vieira Couto. A posição defendida pelo naturalista transparece na seguinte passagem da Memória:

Como a nação que tem indústria, agricultura e comércio e minas é mais rica que outra, que tendo indústria, agricultura e comércio não tem minas, claro fica que só por esta razão devem as minas ser fomentadas. De mais como nenhuma nação, por mais ativa e industriosa que seja, pode bastar a si própria, por não poder ter todos os gêneros de primeira necessidade, luxo ou capricho, porque a natureza não dá a todas tudo

\footnotetext{
${ }^{36} \mathrm{O}$ debate entre aqueles que se colocavam a favor ou contra a recuperação da mineração para o desenvolvimento econômico da nação portuguesa ver a tese de doutorado de: SILVA, Clarete Paranhos da. Garimpando Memórias: as ciências Mineralógicas e Geológicas no Brasil na Transição do Século XVIII para o XIX. Tese (Doutorado em Ciências da Terra). Universidade Estadual de Campinas, Campinas, 2004.
} 
(...) temos por consequência, que o remédio mais pronto é o de animar as minas, e tirar delas todo o partido com que possa pagar o que recebe de fora, e pôr-se ele mesmo no estado de independência. ${ }^{37}$

Ainda que nessa passagem Câmara defenda a importância da mineração como atividade econômica de uma Nação, deixa transparecer em várias das suas memórias a preocupação com a diversificação econômica. A mineração era uma atividade tão importante quanto a agricultura, a pecuária e as manufaturas. Como outros autores que atuaram no mesmo período, Câmara ainda que defendesse a mineração como objeto principal, tecia considerações sobre outros setores da economia. ${ }^{38}$

A primeira parte da Memória divide-se em dois capítulos. No primeiro, o naturalista apresenta uma pequena exposição da história dos descobrimentos das minas na Capitania de Minas Gerais. Destaca a falta "aos paulistas e mineiros", dos principais conhecimentos sobre mineralogia, geometria subterrânea e docimástica, fato que possibilitava apenas que entrassem em contato com o ouro presente à "flor da pele". Dessa forma, não poderiam extrair ouro das pedras das montanhas - segundo o naturalista, ali residia "a origem da extração do ouro mais difícil" - pois seriam necessários importantes conhecimentos científicos para realizar a atividade mineradora. De acordo com o espírito do século das Luzes, Câmara expressou sua confiança na instrução dos mineiros como uma das mais importantes atitudes a serem tomadas para a superação da crise pela qual passava o setor. Tornava-se necessário criar escolas de mineralogia que ensinassem os princípios fundamentais da arte mineira, deixando transparecer a fé na educação e na ciência.

No segundo capítulo, o autor trata das matrizes em que se encontrava o ouro, afirmando que se poderia encontrar o metal em "cascalhos ou em vieiros, ou matrizes quartzosas, vulgarmente minas de pedra". Essa preocupação do naturalista em descrever os locais da ocorrência dos metais, assim como a sua

\footnotetext{
${ }^{37}$ CÂMARA, Manuel Ferreira da. "Memória de Observações Físico-Econômicas Acerca da Extração do Ouro do Brasil (1789)"'. In: MENDONÇA, Marcos Carneiro. O Intendente Câmara. op. cit, , p. 502.

${ }^{38}$ SILVA, Clarete Paranhos da. Garimpando Idéias. A "Arte de Minerar" no Brasil em Quatro Memórias na Transição Para o Século XIX. Revista da Sociedade Brasileira de História da Ciência. Rio de Janeiro, vol.2, n.1, janeiro-junho de 2004, p.38.
} 
matriz, era uma prática que estava de acordo com as modificações pelas quais passava a Mineralogia no final do século XVIII, quando já não importava somente coletar e identificar os materiais minerais, mas verificar como se dava sua distribuição no espaço. ${ }^{39}$ A Mineralogia ia deixando de ser uma ciência essencialmente de laboratório que objetivava tão-somente registrar e sistematizar objetos minerais, e passava a ter uma dimensão geográfica. Em decorrência disso, tornou-se consenso a idéia de que rochas e minerais colecionados em gabinetes podiam dar muito prazer, mas não trariam nenhuma luz à razão se não fossem observados no local de sua ocorrência. ${ }^{40}$ Portanto, Câmara seguia os caminhos próprios de sua ciência, no estágio em que se encontrava naquele período. Estava atento ao que ocorria em relação à ciência que praticava, como bem mostram os seus textos. ${ }^{41}$

Câmara alertou para os erros que os mineiros estavam cometendo na extração do ouro das minas de pedra, uma vez que naquelas o metal encontrava-se "intimamente combinado, e dividido em massas que chegam a nadar ao cume da água". Segundo o autor, o método utilizado pelos mineiros estava trazendo grandes prejuízos ao Estado português. E, de acordo com Câmara, nos mesmos tipos de minas encontradas em Schemnitz e Kremnitz, ${ }^{42}$ a "Coroa da Alemanha" conseguiu obter lucros consideráveis a partir da atividade de mineração.

No terceiro capítulo, o autor apresenta algumas críticas acerca das práticas de mineração e propõe a utilização, em lavra subterrânea, de um ventilador de invenção recente; de um engenho de pilões, por ele aperfeiçoado, antes de o ouro entrar nos moinhos; e ainda de moinhos que favoreciam a cominuição da pedra e amalgamação do ouro. Quanto à separação do metal, fez referência a vasos e fornos em que a destilação do mercúrio se faria com vantagem e ainda

\footnotetext{
${ }^{39}$ RUDWICK, Martin. Minerals, strata and fossils. In: JARDINE, N.; SECORD, J.A.; SPARY, E. C. (org.). Cultures of natural history. Cambridge: Cambridge University Press, 1997.

${ }^{40}$ HAMM, E. P. Knowledge From Underground: Leibniz Mines the Enlightenment. Earth Sciences History. New York, v.16, n.2, 1997.

${ }^{41}$ KURY, Lorelai. Brilhante. Homens de Ciência no Brasil: Impérios Coloniais e Circulação de Informações (1780-1810). História, Ciências, Saúde - Manguinhos. Rio de Janeiro, vol.11, suplemento 1, 2004, p.113; MATOS, Ana Maria Cardoso de. Ciência, Tecnologia e Desenvolvimento Industrial no Portugal Oitocentista. O Caso dos Lanifícios do Alentejo. Lisboa: Editorial Estampa, 1998.

${ }^{42}$ Cidades que pertencem ao atual território da Hungria, importantes centros mineiros desde os tempos dos romanos.
} 
a um método de recuperação deste. E propôs, também, a aplicação do método de fusão à extração do ouro combinado.

No quarto capítulo, Câmara inicia criticando as casas de fundição anexas às minas da América Portuguesa, cuja finalidade era a fusão do ouro, a determinação dos quilates e a percepção do quinto do ouro extraído, destinado à Coroa. Tais funções eram preenchidas de forma deficiente, o que conduzia ao contrabando do ouro e a prejuízos para o Estado português.

A seguir, o autor passa a discorrer sobre a jurisprudência das minas. Critica os princípios, vigentes no Reino, de que interessava mais ao Estado "a divisão do que a terra contém no seu interior, que a extração exclusiva". Tal princípio era exatamente o oposto do que se passava nos Estados "mais civilizados", em que aos soberanos pertencia o direito de extrair as minas, cunhar seu produto e torná-lo próprio à circulação do Estado. Nota-se que Câmara defendia a presença firme do Estado no controle da atividade mineradora e de uma legislação que permitisse racionalizar a produção mineral.

Em conseqüência desse fato, Câmara propôs uma série de medidas destinadas a fomentar as minas, como a redução dos impostos sobre os artigos que mais diretamente serviam à extração (ferro, aço, panos etc.), e sobre os direitos de entrada no Brasil dos escravos destinados às regiões mineiras; a boa regulação e direção das Casas de Fundição; a participação dos descobridores das minas nos lucros das minas; o estabelecimento de companhias de mineiros destinadas à recuperação das minas; e, por fim, o estabelecimento de Casas de conselhos nas províncias mineiras com as funções de: preparar técnicos de minas (geômetras, fundidores e outros homens hábeis) em colégios estabelecidos junto às minas, onde se promovesse o ensino da mineração; verificar os métodos de extração e prover ao aconselhamento técnico aos mineiros que o solicitassem; fazer os ensaios e a fusão do ouro; deliberar sobre a conveniência ou não de fazer a extração de qualquer mina.

De acordo com Câmara, as propostas aqui mencionadas deveriam ser seguidas, uma vez que a legislação sobre as minas da América Portuguesa não facilitava a sua extração. A inspiração para um novo regimento deveria provir dos "estatutos e ordenações das minas mais célebres da Europa", como as da Saxônia, de Eisleben, de Mansfield e do Hart, entre outras, onde por "sábios regulamentos se tem chegado ao cume da felicidade".

Finalmente, Câmara sugere o estabelecimento de colégios nos países mineiros com a função de ensinar tudo o que fosse "necessário à extração dos metais, uma vez que a principal causa, que pode animar a extração das minas, 
em um país favorecido pela natureza, é encaminhar o gênio da nação ao gosto, e prazer da extração delas". ${ }^{43}$ Contudo, defende o autor, que a melhor forma para se adquirir os conhecimentos mineiros seria a experiência prática na própria região das minas.

No ano de 1790, Câmara apresentou a Memória intitulada Observações Feitas Por Ordem da Real Academia de Lisboa Acerca do Carvão de Pedra, Que se Encontra na Freguesia da Carvoeira. Nesse estudo, narra as diligências realizadas com um pedaço de "carvão de pedra piritoso", encontrado no sítio da Freguesia da Carvoeira e levado pelo seu proprietário para ser examinado na Academia. A instituição nomeou o naturalista para examinar o mencionado material mineral e saber se dele poder-se-ia extrair enxofre.

Após realizar as experiências, Câmara constatou que o carvão do sítio da Carvoeira, ainda que não tivesse as mesmas qualidades que o inglês, seria capaz de produzir "os efeitos de uma boa substância inflamável, e que a sua aplicação é mais geral, que a dos carvões mais carregados de partes betuminosas". ${ }^{44}$ Dessa forma, justificava a utilização econômica do recurso natural para ser utilizado como fonte de energia nos fornos e forjas das fundições de ferro e chumbo portuguesas, e diminuir a dependência em relação ao carvão da Inglaterra.

Câmara foi convidado pelo mesmo proprietário do sítio da Carvoeira a analisar outros bancos de carvão em sítios mais altos, como na fazenda "o Casalinho". Aceitou prontamente, uma vez que para ele "era grande desejo que tinha de examinar o interior daqueles montes terciários, e ver se em maior profundidade encontrava banco [de carvão] mais rico". ${ }^{45}$

Na passagem mencionada, Câmara utilizou o termo "montes terciários". Era freqüiente entre os estudiosos da Terra do período aqui estudado fazer uso das expressões "primeira ordem", "segunda ordem" e "terceira ordem". Estes adjetivos estavam de acordo com a nomenclatura do período e correspondiam aos termos "montanhas primárias", "montanhas secundárias" e "montanhas

\footnotetext{
${ }^{43}$ CÂMARA, Manuel Ferreira da. "Memória de Observações Físico-Econômicas Acerca da Extração do Ouro do Brasil”, op. cit., p.522.

${ }^{44}$ CÂMARA, Manuel Ferreira da. "Observações Feitas Por Ordem da Real Academia de Lisboa Acerca do Carvão de Pedra, que se Encontra na Freguesia da Carvoeira (1790)". In: MENDONÇA, Marcos Carneiro de. O Intendente Câmara. op. cit., p.210.

${ }^{45}$ Ibidem, p. 207.
} 
terciárias", respectivamente, dizendo respeito à idade relativa das rochas, sendo as primárias as mais velhas e as terciárias as mais novas. ${ }^{46} \mathrm{O}$ conhecimento da ordem das montanhas da região e da disposição de seus veios seria útil ao desenvolvimento da arte de minerar, na medida em que isso resultaria na aplicação de técnicas mais adequadas à mineração dos montes, uma vez que, por possuírem veios que entravam para o centro da Terra, sua mineração teria de ser necessariamente diferente da dos rios, onde a ocorrência do ouro era superficial.

A seguir, Câmara forneceu informações sobre a composição dos bancos de carvão presentes no monte analisado. Assinalou também como uma das razões para pesquisar os bancos de carvão em montes de maior altura a existência de "indícios de antigas minas de carvão, que nos montes superiores, e na direção de leste a oeste se encontram" ${ }^{47}$ Essa praxis científica de estudar e analisar minerações antigas não era apanágio de Câmara, fazendo-se presente também nas memórias mineralógicas de José Bonifácio. ${ }^{48}$ Os exemplos históricos forneciam a chave para a viabilidade da exploração das minas, bem como a racionalidade das "luzes" poderia permitir retomar o aproveitamento dessas antigas minerações, a partir de novos conhecimentos.

A leitura de diversos trechos da memória nos permite observar uma linguagem que se caracteriza como o conjunto das práticas científicas mineralógicas do século XVIII, segundo a historiadora das geociências Rachel Laudan. ${ }^{49}$ Era consenso, entre os estudiosos, o conhecimento de que a crosta terrestre era formada por terras, metais, sais e substâncias betuminosas. Essas classes de minerais poderiam ser diferenciadas umas das outras por suas reações ao fogo ou à água, ou, então, por esses minerais terem sido fluidos, tendo se solidificado por retirada de água ou de calor. Esse conjunto de questões foi o que Laudan chamou de conjunto de práticas científicas da mineralogia no século XVIII. Câmara empregou termos como pedras, terras, minerais, sais, enxofres e metais, seguindo assim esse conjunto de práticas.

A dissertação possibilita observar quais os sistemas de classificação dos minerais que Câmara utilizava. Em suas pesquisas pelo sítio da Carvoeira,

\footnotetext{
${ }^{46}$ RUDWICK, op. cit.

${ }^{47}$ CÂMARA, Manuel Ferreira da. "Observações Feitas Por Ordem da Real Academia de Lisboa Acerca do Carvão de Pedra...", op. cit., p. 207.

${ }^{48}$ VARELA, op. cit.
} 
recorreu a três tipos diferentes de sistemas de classificação para descrever as variedades de carvão ali encontradas. A descrição presente no sistema de classificação de Johan Gottschalk Wallerius foi a que, segundo o naturalista, melhor poderia ser apropriada para o material mineral encontrado, sobretudo a descrita no "gênero 6, variedade primeira, Lithantrax ligneus". Informava também que o carvão encontrado no sítio da "Panasqueira" inseria-se melhor na "variedade quarta Litrantax fisilis”. Quanto ao carvão piritoso, informou a classificação como "petrificados, ordem segunda gênero 62, espécie 17, variedade segunda". ${ }^{50}$

Câmara informa que o naturalista sueco Carl von Linné (Lineu) compreendia todas as variedades apresentadas na "espécie sete, gênero 21 da ordem segunda das minas Bitumen schistosum". Já no sistema de Richard Kirwan (1733-1812), o carvão piritoso foi descrito na "variedade quarta das substâncias inflamáveis, espécie nona, e o que não é piritoso, parte compete à variedade primeira e segunda, parte à terceira". ${ }^{51}$

Ao identificar e descrever o carvão nos sítios pesquisados, observa-se que Câmara fez uso dos sistemas de classificação de minerais de Wallerius, de Lineu e de kirwan. O botânico Lineu classificou os minerais seguindo o modelo que ele utilizava para classificar as plantas, enfatizando os seus caracteres externos. Rachel Laudan observou que esse modelo foi bastante empregado nas classificações de minerais nos anos que se seguiram ao seu surgimento, em 1735, mas começou a ser criticado pela maioria dos mineralogistas à medida que estes iam percebendo que o "reino mineral e o reino vegetal diferiam tão radicalmente que os conceitos e métodos que funcionavam para o último não poderiam ser aplicados ao primeiro". ${ }^{52}$

O sistema de classificação de Wallerius baseava-se em modelo químico, e dava ênfase aos caracteres internos dos minerais. Esse estudioso distinguia os caracteres internos e os externos dos minerais. Os caracteres externos que permitiriam a classificação eram a cor, o gosto, a forma, o cheiro, os usos e a

${ }^{49}$ LAUDAN, Rachel. From mineralogy to geology: the foundations of a science, 1650-1830. Chicago: The University of Chicago Press, 1987.

${ }^{50}$ CÂMARA, Manuel Ferreira da. "Observações Feitas Por Ordem da Real Academia de Lisboa Acerca do Carvão de Pedra...”, op. cit., p. 210.

${ }^{51}$ Ibidem, p. 210.

${ }^{52}$ LAUDAN, op. cit. 
ocorrência. Quando não fosse possível a classificação por meio desses caracteres externos, processavam-se análises químicas..$^{53}$

\section{III- A Viagem Científica Pela Europa Central e Setentrional}

No espaço da Academia Real das Ciências de Lisboa, Câmara e José Bonifácio despertaram as atenções de alguns membros, entre os quais o duque de Lafões. Como resultado da admiração deste último, ganharam uma bolsa de estudos do governo português para fazer uma viagem científica pela Europa, juntamente com Joaquim Pedro Fragoso. Para a realização desse empreendimento, o ministro Luiz Pinto de Souza baixou uma minuciosa Instrução para a realização da viagem de aperfeiçoamento técnico através da Europa (31.5.1790). Nela determinou-se que Manuel Ferreira da Câmara seria o "chefe de Brigada", sendo responsável pela "decisão do tempo dos estudos e das viagens, do destino de cada um dos sócios, e dos sítios onde deviam empregar-se". ${ }^{54}$

O recebimento da bolsa de estudos para a realização da viagem oferecida pelo governo português deixou transparecer a inserção de José Bonifácio e Ferreira da Câmara na Lógica do Prestígio, ${ }^{55}$ na medida em que viviam sob a proteção do Estado (através de cargos, pensões, mesadas etc.). Vivendo literalmente às custas da Coroa portuguesa, passavam a ter uma posição privilegiada em sua sociedade. Privilegiada porque significava a proximidade com a Coroa, a participação em sua vida, e o recebimento de pensões. Privilegiada porque dependente. Portanto, o trabalho dos dois naturalistas não pode ser dissociado do seu papel enquanto cortesões, uma vez que a vida na corte moldaria a sua vida quotidiana e a sua atividade científica. E, na corte, espaço social onde as regras eram determinadas pelo príncipe, a história natural desfrutava de amplo reconhecimento, uma vez que teria um papel central nos projetos econômicos, políticos e culturais da segunda metade do século XVIII no Império Português. ${ }^{56}$

\footnotetext{
${ }^{53}$ GUNTAU, Martin. "The natural history of the Earth". In: JARDINE, N.; SECORD, J. A.; SPARY, E. C. (Orgs.). Cultures of NaturalHhistory. Cambridge: Cambridge University Press, 1997.

${ }^{54}$ FALCÃO, Edgard de Cerqueira (Org.). Obras científicas, políticas e sociais de José Bonifácio de Andrada e Silva. vol. III. Santos: Revista dos Tribunais, 1963, p. 169.

${ }^{55}$ ELIAS, Nobert. A Sociedade de Corte. Lisboa: Editorial Estampa, 1995.

${ }^{56}$ BIAGIOLI, Mario. Galileu, Cortesão. A Prática da Ciência na Cultura do Absolutismo. Porto: Porto Editora, 2006.
} 
Cabe registrar que a atuação de Manuel Ferreira da Câmara, personagem que vivia na sociedade do Ancien Régime, teve a sua carreira enquanto naturalista caracterizada por encerrar-se completamente na fidelidade a uma espécie de dupla identidade, como assim constatou Vicenzo Ferrone ${ }^{57}$ em sua análise sobre o estudioso das ciências do século XVIII.

Primeiro, observa-se a sua adesão ao modelo do homem de ciência organicamente ligado ao Estado, que aceitava inteiramente a lógica e os valores de uma sociedade hierarquizada, estabelecida, organizada por ordens, classes, e corpos diferenciados pelas dignidades, honras, onipresença do privilégio e categorias. O Estado atribuía ao estudioso das ciências honras e privilégios, conforme o costume e a lógica do Ancien Régime, privilégios que iam desde uma isenção parcial dos rendimentos à dispensa do serviço militar, à enorme possibilidade de ser levado à presença do rei, ao recebimento de bolsas de estudo, participação no cerimonial da corte e nas manifestações públicas. O compromisso com o monarca e com o sistema de organização da vida intelectual assente no patronage permitia, aliás, desenvolver a fundo as potencialidades do método científico e aumentar o número dos protagonistas em virtude dos financiamentos, das pensões, dos privilégios distribuídos pelo soberano. O homem de ciência do século XVIII, no contexto do antigo regime, era basicamente um funcionário do Estado, cujas atividades eram financiadas pelos monarcas, revelando assim o pacto tácito com o poder.

Observa-se, entretanto, na prática científica do naturalista, a adesão e difusão do enciclopedismo, a ideologia científica do progresso, o utilitarismo e o pragmatismo, assim como a vontade e o desejo de classificar os elementos do mundo natural, traços que caracterizam o moderno pensamento científico. Ademais, registremos o fato de ser membro da "República das Letras", com os seus valores cosmopolitas, uma vez que participava ativamente de inúmeras sociedades científicas e publicava os trabalhos de suas pesquisas que seguiam o método moderno da observação e da experimentação.

$\mathrm{Na}$ Instrução estavam listados determinados locais por onde os filósofos deveriam passar. O percurso, longe de ser delineado arbitrariamente, era estipulado pelo poder administrativo. Em segundo lugar, os participantes contariam

\footnotetext{
${ }^{57}$ FERRONE, Vicenzo. "O homem de ciência”. In: VOVELLE, Michel (Org.). O homem do Iluminismo. Lisboa: Editorial Presença, 1997.
} 
com uma ampla rede de diplomatas em todos os locais que visitassem, facilitando a entrada e a permanência nos países determinados pelo poder régio.

Primeiramente deveriam ir à França, país expoente da Ilustração européia e onde ocorreu a chamada "revolução química", liderada por Antoine Laurent Lavoisier, e também importante centro em que se desenvolveu a Escola de Mineralogia Cristalográfica, que teve como expoentes Romé de L'Isle e o abade René-Just Haüy. Em Paris deveriam fazer um curso completo de química com M. Fourcroy (Antoine François de Fourcroy, 1755-1809) e outro de mineralogia docimástica com M. Le Sage (Balthazar-Georges Sage, 1740-1824).

José Bonifácio e Câmara fizeram o curso de Fourcroy. Ao freqüentar as aulas desse importante químico francês, os estudiosos entraram em contato com as principais idéias da "revolução química", uma vez que Fourcroy colaborou para a formulação da "nova" nomenclatura química, baseada na teoria da oxidação e da combustão, e que negava a existência do flogisto. Aceitar a nova nomenclatura significava, assim, aderir às novas idéias. ${ }^{58}$

Por sua vez, o curso de mineralogia programado para ser lecionado pelo professor Le Sage não foi realizado sob a sua responsabilidade, mas pelo professor Guillot Duhamel, na Escola de Minas de Paris. Se tivessem feito o curso de Le Sage, José Bonifácio e Câmara teriam estudado a mineralogia docimástica, área de especialização do estudioso francês. O curso que Duhamel oferecia na Escola de Minas estava relacionado "à arte do minerador, à arte do metalurgista, à geometria elementar subterrânea, teórica e prática, ou ao tratado dos filões ou veios mineralógicos e sua disposição pelo seio da terra" ${ }^{59}$

Após o período na França, os naturalistas passaram pela Holanda e, a seguir, dirigiram-se, seguindo a Instrução, para Freiberg, na Saxônia, centro mais avançado em mineração e estudos correlatos da Europa, além de sediar a primeira academia de minas do mundo, a Bergakademie Freiberg. Nesse local, José Bonifácio e Câmara assistiram ao curso de orictognosia e geognosia administrados pelo professor Abraham Gottlob Werner, de quem se tornariam discípulos.

\footnotetext{
${ }^{58}$ BENSAUDE-VINCENT, Bernadette; STENGERS, Isabelle. História da química. Lisboa: Instituto Piaget, 1996.

${ }^{59}$ ARLET, Gabriele. D’héphiasitos à Sphia Antipolis-mineurs et forgérons. vol. I. Paris: St. Etienne, Gédim, 1991, p.97.
} 
A geognosia (literalmente, 'conhecimento da terra') era o campo da mineralogia relativo à classificação das massas das rochas e suas relações espaciais. Os geognostas, como eles próprios se chamavam, tentavam definir e descrever as formações que seriam reconhecidas para além de uma simples região, alcançando escalas globais. A tarefa de reconhecer formações em diferentes locais e, assim, tornar a classificação tão aplicável quanto fosse possível foi tentada empiricamente por diferentes critérios. ${ }^{60}$

Abraham Gottlob Werner foi sem dúvida o responsável pela institucionalização da geognosia. Ele não foi o criador dessa ciência, uma vez que ela era o resultado científico de um saber muito mais antigo, originário da Europa Central e da Suécia, sendo que outros autores já haviam usado a expressão em suas publicações. ${ }^{61}$ Para o saxão, a geognosia era uma subdivisão da mineralogia. Ela distinguia-se da mineralogia geográfica, que estudava a distribuição das rochas e dos minerais pela superfície, e da orictognosia, a qual estudava as substâncias 'fósseis' do subsolo.

A apropriação das idéias de Werner pelos dois estudiosos portugueses fica clara a partir da leitura de seus textos, onde termos e idéias netunistas ${ }^{62}$ estão presentes, bem como das dedicatórias de próprio punho em cópias impressas de seus trabalhos. Por exemplo, Câmara publicou no ano de 1794, na revista da Academia de Freiberg, Bergmanniches Journal, dois artigos sobre a obsidiana em que compartilhava claramente o netunismo. ${ }^{63}$

Após a estada em Freiberg, onde obtiveram conhecimentos que os prepararam como mineiros, Câmara e Bonifácio visitaram diversas minas na Áustria, no Tirol, na Caríntia, na Estíria e no norte da Itália. Após estarem juntos em todos os locais até agora mencionados, em janeiro de 1796 partiram para rumos

\footnotetext{
${ }^{60}$ RUDWICK, op. cit.

${ }^{61}$ ELLEMBERGER, François. Histoire de la géologie. Paris: Technique et Documentation, Lavoisier, 1994, p.246.

${ }^{62}$ Os netunistas eram seguidores do modelo do mineralogista saxão Werner, o qual atribuía à água o papel preponderante na formação da crosta terrestre, em contraposição ao escocês James Hutton, defensor da teoria denominada plutonista, que enfatizava a ação interna como a responsável pela formação das rochas. Sobre a controvérsia entre netunistas e plutonistas ver: HALLAM, Anthony. Grandes Controvérsias Geológicas. Barcelona: Labor, 1982.

${ }^{63}$ FIGUEIRÔA, op. cit., p.218.
} 
diferentes. Câmara foi visitar as minas da Transilvânia e do Banat. ${ }^{64}$ Por sua vez, Bonifácio foi em direção à Alta Hungria. Depois, individualmente, visitaram regiões mineiras da Suécia, Noruega e Dinamarca. Câmara ainda esteve na Inglaterra, visitando as minas de carvão e as de extração de metais, enquanto Bonifácio não esteve por lá. Pelas informações que obtivemos, os estudioso não visitaram as minas de Ekatharinemburgo, na Rússia e também não foram à Espanha, visitar as minas de Almadén.

Na região da Transilvânia, importante centro europeu de tradição de exploração de metais nobres, Câmara elaborou um texto intitulado Nota Sobre a Extração das Minas do Principado da Transilvânia escrita em Zalathna aos cinco dias do mês de março de $1796{ }^{65}$

A primeira parte do estudo versa sobre a legislação mineira e a administração das minas nos Estados Austríacos, que tinha como base a alemã. Câmara deu relevância aos seguintes pontos: o direito de extrair minas pertencia à competência do Soberano; o Imperador poderia conceder o direito a qualquer um para explorar as minas, como também era obrigado a ajudar e socorrer às companhias mineiras; cada região mineira seria administrada por um Conselho comandado pelo Soberano; a administração dos bosques estava unida ao conselho das minas; os "corpos de minas" eram independentes de qualquer jurisdição civil ou política; e, havia um Conselho de Finanças que tinha a seu cargo a administração e inspeção das minas, e cujos conselheiros eram instruídos na arte das minas e na economia montanhística. De acordo com o estudioso, esses foram

\footnotetext{
${ }^{64}$ Região geográfica e histórica da Europa Central atualmente dividida entre três países: na Romênia (os condados de Timis, Caras-Severin, Arad e Mehedinti), na Sérvia (localizado em sua maior parte na Voivodina) e uma pequena parte na Hungria (Condado de Csongrád).

${ }^{65}$ Região da Europa Central que constitui a atual zona centro-ocidental da Romênia. De acordo com Manuel Serrano Pinto, as razões que fizeram Câmara viajar para Zalathna e visitar a Transilvânia, passando lá o inverno de 1795/1796, foram: o excelente conceito das técnicas de fundição lá praticadas; a administração das atividades de mineração deveriam ser estudadas e comparadas com aquelas feitas no Brasil; e, a administração geral da Transilvânia era centrada em Zalathna. Ainda seguindo o mesmo autor, no momento da visita de Câmara, o Soberano Habsburgo era Leopoldo II. A Transilvânia estava sob a dominação austríaca desde a ocupação feita por Leopoldo I em 1691. PINTO, Manuel Serrano. "A Memoir Written in 1796 By Manoel Ferreira da Camara About Mining in Transylvania". In: INHIGEO Meeting. Geological Resources and History. June $24^{\text {th }}$-July $1^{\text {st }} / 2001$. Proceedings of the $26^{\text {th }}$ INHIGEO Symposium. Aveiro: Universidade de Aveiro/Centro de Estudos de História e Filosofia da Ciência e da Técnica, 2003, pp. 363-372.
} 
"os fundamentos sobre que se fundaram as administrações mineiras, que me são conhecidas; foram estes os meios que tenho visto fazer uso por toda a parte para as minas, regular, e simplificar a extração das minas". ${ }^{66}$

A seguir, Câmara passou a informar detalhadamente as "diferentes partes da administração montanhística da Transilvânia", mencionando os diversos metais extraídos e a forma como o Soberano considerava a importância de cada um em particular.

Segundo Câmara, o ouro era o principal objeto da extração e da administração Imperial. Ele era encontrado em abundância na Transilvânia e explorado em vários locais. O metal ocorria de duas formas: o ouro localizado, encontrado nos veios dos rios e nas suas margens, originário das montanhas vizinhas e tendo sido para ali transportado pela água no passado; e o ouro disseminado, encontrado no interior da terra em veios, bancos ou camadas, em rochas que não tinham suas partes cortadas. As duas formas do metal foram chamadas por Câmara de "ouro nativo", enquanto o ouro associado com a prata foi chamado de "ouro mineralizado", obviamente pelo fato de ser menos puro que o nativo.

Quanto aos outros metais encontrados na Transilvânia, Câmara informou que se explorava a prata encontrada sempre mineralizada com ouro; o cobre não era um produto de interesse na região, uma vez que se extraía em Bonato e na Hungria; e, as ocorrências de ferro e de chumbo eram escassas.

Mais tarde, Câmara forneceu detalhes sobre os corpos institucionais da administração das minas nos Estados austríacos e na Transilvânia em particular. De forma similar ao que acontecia nos Estados germânicos, como a Saxônia e o eleitorado de Hannover, havia um Grande Conselho ou Colégio de cada Estado austríaco encarregado da jurisdição, administração e inspeção das minas. Em certos casos, o Conselho também encontrava-se encarregado da jurisdição civil e criminal. Em cada distrito mineiro havia um conselho composto por um superintendente, por vários conselheiros e juristas, por um diretor dos trabalhos montanhísticos, por um diretor dos trabalhos de fundição, e por diversos funcionários subalternos.

${ }^{66}$ CÂMARA, Manuel Ferreira da. Nota Sobre a Extração das Minas do Principado da Transilvânia Escrita em Zalathna aos 5 de março de 1796. Loc.: Arquivo Nacional da Torre do Tombo. Núcleo do Ministério dos Negócios Estrangeiros, Caixa 526, folhas 4-5. 
A administração do conselho das minas na Transilvânia, localizada em Zalathna, tinha o ministro das finanças do principado como o seu presidente. Esse conselho era composto ainda por um vice-presidente, por um diretor dos trabalhos montanhísticos, por um diretor dos trabalhos de fundição, por um recebedor-mor de ouro em pó, e por diversos funcionários subalternos. A função do conselho era assegurar o bom curso das atividades de mineração no principado e receber os direitos imperiais da indústria mineira.

Em diversos momentos do estudo, Câmara fez referências à mineração na América Portuguesa e em Portugal para servir de sugestões naquilo que deveria ser feito em termos de administração. O sistema alemão é que deveria ser seguido, como ocorrera na Transilvânia e em outros Estados austríacos, com o objetivo de modernizar, regularizar e simplificar a indústria das minas. Também fez diversas sugestões técnicas, apontou a necessidade de se mudar a legislação das minas em Portugal, e aconselhou o governo português a tomar medidas administrativas similares às da Transilvânia em relação ao ouro em pó e ao ouro nativo. Câmara enfatizou a idéia de que, para a Rainha de Portugal, seria mais fácil tomar medidas administrativas com o intuito de realizar uma boa extração e práticas de fundição levando em consideração as especificidades das leis fundamentais do Estado português e a diversidade das comunidades que lá residiam, como procedeu o Soberano Austríaco na Transilvânia.

A viagem de formação teórica e prática no campo da metalurgia e da mineração por diversos países da Europa Central e Setentrional fazia parte da política portuguesa que visava arregimentar os estudiosos portugueses, nascidos ou não na metrópole, com o intuito de ajudar a promover a regeneração do Império. ${ }^{67}$ Não foi por acaso que a maioria desses ilustrados coloniais, entre os quais os

\footnotetext{
${ }^{67}$ Todo um conjunto de análises historiográficas tem mostrado como os Ilustrados, tanto do Reino, como da colônia, e aí inseridos Bonifácio e Câmara, elaboraram inúmeras propostas de modernização para o Estado lusitano, deixando assim transparecer o interesse pela manutenção da união entre Brasil e Portugal. Ver: ARAÚJO, Ana Cristina. "Um Império, um Reino e uma Monarquia na América: As Vésperas da Independência do Brasil”. In: Jancsó, István (org.). Independência: História e Historiografia. São Paulo: FAPESP; Editora HUCITEC, 2005; LYRA, Maria de Lourdes Viana. A Utopia do Poderoso Império: Portugal e Brasil: Bastidores da Política, 1798-1822. Rio de Janeiro: Sette Letras, 1994; DIAS, Maria Odila da Silva. "A Interiorização da metrópole”. In: MOTA, Carlos Guilherme (Org.). 1822 - Dimensões. São Paulo: Perspectiva, 1972; Idem. "Aspectos da Ilustração no Brasil". Revista do Instituto Histórico e Geográfico Brasileiro. Rio de Janeiro, vol.278, janeiro-março de 1968, pp.105-170.
} 
dois mencionados naturalistas, pertenciam ao grupo de D. Rodrigo de Sousa Coutinho, ministro de D. Maria I desde 1796, que defendia a fundação de um Império luso-americano, com sede na sua porção mais rica, o Brasil, como solução à crise que se abatia sobre o Reino.

Nessa viagem, eles foram enviados para os principais distritos mineiros europeus, bem como para importantes centros técnico-científicos de grande destaque à época, como Freiberg, França e Saxônia, entre outros. O intuito dessa viagem foi o de observar o estado das ciências nesses países e de se aperfeiçoar, para assim poderem levar para Portugal os ares da modernidade. Essa prática de adesão às ciências modernas era buscada em diferentes lugares, selecionando os conhecimentos que mais lhes interessavam, uma vez que os centros científicos nem sempre eram os mesmos. A viagem, portanto, deixava transparecer o caráter exterior e eclético da Ilustração portuguesa.

A dimensão política vinha acoplada à dimensão científica. A viagem fazia parte do processo de modernização do Estado português no período do governo de D. Maria I. O Estado português buscou, na época, incentivar a formação de funcionários especializados com o intuito de ocupar cargos públicos estratégicos, sobretudo no campo da administração das minas. Após a realização dessa viagem, José Bonifácio e Manuel Ferreira da Câmara viriam a ocupar importantes funções no campo da mineração em Portugal e na colônia, destacando-se ambos na administração conjunta das minas, matas e bosques. Os dois naturalistas aplicaram o seu saber científico a serviço da nação portuguesa, com o intuito de contribuir para as reformas que visavam regenerar o Império lusitano. Acima de tudo, eles eram portugueses, fiéis vassalos da Monarquia dos Braganças, comungando uma "identidade política coletiva" que remetia ao Estado português. ${ }^{68}$

\footnotetext{
${ }^{68}$ Como argumentaram István Jancsó \& João Pimenta, "nada de brasileiros, nenhuma identidade política ultrapassando o regional. Na verdade, isso não é de surpreender. A força coesiva do conjunto luso-americano era indiscutivelmente a Metrópole, e o continente do Brasil representava, para os colonos, pouco mais que uma abstração, enquanto para a metrópole se tratava de algo muito concreto, a unidade cujo manejo impunha esta percepção. É por isso que é correto afirmar que a "apreensão de conjunto das partes a que 'genericamente' se chamou de Brasil" estava no "interior da burocracia estatal portuguesa". JANCSÓ, István; PIMENTA, João Paulo Garrido. "Peças de um Mosaico (apontamentos para o estudo da emergência da identidade nacional brasileira)". In: MOTA, Carlos Guilherme (org.). Viagem Incompleta 1500-2000 - A Experiência Brasileira. São Paulo: SENAC São Paulo Editora, 2000, p.140.
} 
Para Câmara e José Bonifácio, a viagem foi imprescindível para a especialização de suas respectivas trajetórias como naturalistas. Os dois tornaramse, como eles próprios afirmavam, "metalurgistas de profissão".

\section{IV- 0 Cargo de Consultor do Governo em Assuntos de Minas e Metalurgia}

Ao retornar a Portugal, em 1798, ${ }^{69}$ Câmara foi contratado pelo Estado português para ser o consultor do governo em assuntos de minas e metalurgia. Esse fato indica a valorização daqueles que detinham o conhecimento científico e técnico por parte dos homens de governo português. Em síntese, demonstrase o reconhecimento do poder da ciência pelo Estado. ${ }^{70}$

Vale relembrar que o ministro da Marinha e do Ultramar do governo de D. Maria I, Dom Rodrigo de Sousa Coutinho, apresentou um projeto políticoreformista de modernização da administração do Império Português, projeto este que tinha como base a Memória Sobre o Melhoramento dos Domínios de Sua Majestade na América. A Memória foi submetida a Ferreira da Câmara para que ele desse o seu parecer. Logo de início, Câmara informou que em relação às "grandes, novas e liberais idéias de D. Rodrigo de Sousa Coutinho sobre a futura administração política dos estados ultramarinos, e particularmente do Brasil" acrescentaria algumas idéias sobre a "economia mineral daqueles estados", ou melhor, um "sistema geral de economia mineral". ${ }^{71}$

De acordo com o naturalista, as minas deveriam ser administradas por um Conselho, Junta ou Administração, com poderes completamente independentes dos governadores. A administração mineira ficaria sob a influência direta do Conselho de Ultramar ou do Conselho de Finanças do Reino. A vantagem dessa forma de organização residia no fato de garantir a homogeneidade nas normas de administração das minas uma vez que, dada a constante mudança de governadores, acabavam sofrendo na sua orientação administrativa mudanças sempre

\footnotetext{
${ }^{69}$ José Bonifácio regressou a Portugal somente em 1800.

${ }^{70}$ MATOS, Ana Maria Cardoso de. "A ciência a serviço da reforma do Estado: a química em Portugal no final do século XVIII e início do século XIX”. In: JANEIRA, Ana Luísa et all (Org.). Divórcio entre cabeças e mãos? Laboratórios de química em Portugal (1772-1955). Lisboa: Livraria Escolar Editora, 1998.

${ }^{71}$ CÂMARA, Manuel Ferreira da. "Memória Sobre o Trabalho de D. Rodrigo. Lisboa, 13/ 08/1798”. In: MENDONÇA, Marcos Carneiro. O Intendente Câmara. op. cit., pp.54-55.
} 
nocivas aos superiores interesses da administração. Daí, a necessidade de se ter um "plano constantemente seguido e ditado por homens que se ao menos não entrassem nela com toda a experiência que se requer, a pudessem ganhar com o tempo". ${ }^{72}$

Câmara observou a independência administrativa das minas com relação ao "poder civil e militar", e os resultados positivos dessa separação em regiões da Europa, como Hannover, Saxônia, Rússia, Noruega, entre outras. Tomando como exemplo essas regiões, o estudioso defendeu a adoção de tal sistema administrativo das minas, segundo ele, extremamente útil e vantajosa para o Brasil.

O naturalista criticou as leis de mineração adotadas nos Domínios Ultramarinos. Contudo, melhorá-lhas seria impossível, pois, na realidade, o que havia era apenas um "esqueleto do sistema alemão", que de forma alguma se executava no Brasil, e também um regimento de terras e águas minerais, que Câmara dizia não conhecer, embora desejasse ver.

O naturalista argumentou sobre a importância da administração das matas e a sua utilidade econômica para a nação portuguesa. Informou que, como ocorria na Alemanha e também em Portugal, a administração dos bosques deveria estar associada à das minas. Tal função deveria ser exercida por "homens peritos" que associassem aos conhecimentos metalúrgicos aqueles relacionados à botânica, e vigiassem sobre a conservação dos bosques para que estes pudessem vir a ser de grande utilidade no futuro.

A seguir, comentou sobre a necessidade de se isentar o mineiro de todo emprego militar e marítimo, privilégios estes de que ele gozava por toda a Europa. Desarmá-lo em vez de o armar, como se estava fazendo, era a seu ver muito conveniente. Tinha mais uma vez como referência países de tradição mineira como a Rússia, a Hungria, a Alemanha, e particularmente a Saxônia, onde a necessidade de manter em pé grande força militar era bem conhecida e nunca o mineiro era chamado à guerra, senão para abrir minas, quando necessário.

Câmara parabenizou D. Rodrigo pelo fato de ter abolido a maior parte das imposições estabelecidas para a Capitania de Minas Gerais por asfixiarem, desde a sua origem, as fontes de riqueza pública. Criticou o contrato do sal e o das entradas, pelo fato de taxarem com pesada mão os gêneros de primeira necessidade e os produzidos no Reino, para claramente favorecerem os de luxo - o

${ }^{72}$ Ibidem, p.56. 
ferro com que se trabalha nas minas, além de 90 por cento, e as cambraias e as sedas, de dois a quatro por cento. Criticando a persistência essas imposições, o naturalista afirmou que: "nunca poderemos com ferro e aço estrangeiro fazer as máquinas necessárias no centro das minas, com que possamos arrancar das entranhas da terra tudo que ela encerra: havendo-se muitas vezes de fundir grandes cilindros de ferro coado, que transportados aos centros das minas não importariam em tanto, que o seu produto os não pudesse pagar". ${ }^{73}$

Câmara apresentou ainda toda uma argumentação em prol do estabelecimento e multiplicação de fábricas de ferro por toda a América Portuguesa. Tais estabelecimentos proporcionariam ao Rei de Portugal um considerável "ramo de finanças", que a princípio o indenizaria de grande parte dos sacrifícios que se deveriam fazer para recuperar as minas de ouro e para extrair de todas as outras riquezas que poderiam ser encontradas em toda a colônia, como por exemplo a prata e o cobre.

O naturalista afirmou que a existência de ferro em terras da América Portuguesa era algo certo, e de pronto informou sobre a presença de dois ricos minérios de ferro, conhecidos pela sua utilização econômica: a "pedra de cevar" e a "mina de ferro micácea". A presença de carvão era dada também como algo certo, a não ser que continuassem a destruir as matas e os bosques. A presença de uma grande diversidade de animais de carga facilitaria o transporte dos minerais e do carvão. E, a utilização da mão-de-obra escrava nesta tarefa contribuiria para que Sua Majestade vendesse o ferro com um lucro de 10 a 15 por cento em relação ao seu custo.

A preocupação do governo português em incentivar a criação de fundições de ferro advinha da importância que o metal adquiriu em função das necessidades da Revolução Industrial, sobretudo a produção de lâminas de ferro e a produção de aço em larga escala. A política do governo metropolitano, no final do século XVIII, foi orientada para a tentativa de se implantar a instalação da fabricação de ferro em Portugal e na América Portuguesa, com vistas a promover o progresso de ambos. ${ }^{74}$

\footnotetext{
${ }^{73}$ Ibidem, p. 59.

${ }^{74}$ NOVAIS, op. cit., p.285.
} 
O interesse da Coroa portuguesa com a exploração e o estabelecimento de fábricas de ferro na colônia explica-se como uma conseqüência do esgotamento das minas de ouro, obrigando Portugal a procurar algum produto que pudesse substituir a outrora infindável riqueza. $\mathrm{O}$ ferro passou a ser mencionado como um produto passível de prover o Erário Real dos numerários indispensáveis à manutenção da monarquia portuguesa. Ademais, vale frisar que a Revolução Industrial inglesa colocou esse minério, juntamente com o carvão, como os principais produtos que determinariam a supremacia de uma nação sobre a outra.

Após esse parecer, ${ }^{75}$ Câmara foi enviado para realizar um estudo sobre as montanhas da região do Centro de Portugal. Em tal localização, examinou as montanhas da região da Batalha, e nelas identificou a continuação das do Porto de Móz, onde afirmou ter encontrado provas "mais decisivas da existência do carvão a pouca distância das cavas de Aviche". Prosseguindo a sua viagem, afirmou ter examinado os "montes das vizinhanças de Leiria", onde afirmou ter encontrado a mesma "formação". ${ }^{76}$ A afirmação de que as montanhas de uma determinada região tinham a mesma disposição que as de outras partes, insere-se dentro da prática científica geognóstica de Werner, que afirmava que a análise cuidadosa de uma região permitia o reconhecimento da ordem universal das formações da Terra. ${ }^{77}$

A preocupação com o estudo das montanhas era uma característica da mineralogia do século XVIII. Isso porque, como afirmou Gohau, uma das várias utilidades das montanhas encontrava-se no fato de serem locais favoráveis à exploração de jazidas metálicas. Além disso, cabe sublinhar que o estudo das montanhas e de suas origens foi um tema preferido pelos netunistas. Isso porque o termo montanha não designava apenas a parte mais elevada da crosta terrestre, mas todo o depósito que tivesse ocorrido em uma mesma idade. Dessa forma, a compreensão da origem dos montes significava a compreensão da origem da própria crosta terrestre. ${ }^{78}$

\footnotetext{
${ }^{75}$ Em 29 de agosto de 1798, Câmara apresentou um parecer sobre a memória da fábrica de ferro existente em Galingo, no Reino de Angola, escrita por José Álvares Maciel. Esse parecer não será analisado aqui nesse texto e encontra-se em MENDONÇA, op. cit., pp. 300-305.

${ }^{76}$ Ofício de Manuel Ferreira da Câmara sobre o estado atual da mata do Pinhal de Leiria. Thomar, 24/10/1798. Loc.: Instituto Histórico e Geográfico Brasileiro (IHGB) L. 107 Pasta 23, folha 1 .

${ }^{77}$ GOHAU, Gabriel. História da Geologia. Lisboa: Publicações Europa-América, 1988, p.96.

${ }^{78}$ Ibidem, pp.53 e 96-98.
} 
Na região de Leiria, o estudioso visitou o chamado Pinhal de Leiria, ${ }^{79}$ elaborando um parecer sobre o estado em que ele se encontrava. E, de imediato, diagnosticou a péssima situação em que se achava o pinhal, convocando D. Rodrigo para acompanhá-lo numa visita até o local. De forma incisiva, destacou para o ministro a necessidade de uma reforma urgente da reserva florestal e a sua importância para a nação portuguesa:

A conservação, aumento e duração do pinhal de Leiria são objetos tão importantes para a Real Marinha, que bastaria dizer, que este é para assim o dizer, o único bosque que temos para o provar, mas infelizmente acha-se sobre maneira estragado, ou arruinado, sem que todavia possamos atribuir a sua ruína à outra coisa, que a da falta de luzes entre nós sobretudo que respeita a plantação, e conservação dos bosques: não os temos, e tanto basta, para que disso não tenham cuidado. A velhice das árvores, que aí se encontram, mais do que a sua natureza, torna respeitável aquela mata sobre as poucas que há em Portugal. ${ }^{80}$

A preocupação explícita do naturalista com a conservação do pinhal residia no fato de ele servir como fonte energética para alimentar fornos das indústrias metalúrgicas e de vidro, como também para o aquecimento das populações. $\mathrm{O}$ governo português parece ter ouvido as palavras de Câmara, tanto que reconhecendo a importância e a necessidade de uma intervenção no setor florestal, contratou o naturalista José Bonifácio para exercer o cargo de Guarda-Mor dos Bosques e Matos, indivíduo que tinha as "luzes" do conhecimento sobre a plantação e conservação dos bosques. Em sua viagem de especialização científica pela Europa Central e Setentrional, Bonifácio freqüentou o curso do conde de Burgsdorff, Monteiro-mor de Brandeburgo, inteirando-se assim dos conhecimentos práticos

\footnotetext{
${ }^{79} \mathrm{O}$ antigo Pinhal de Leiria está situado a norte de Leiria, na Mata Nacional do Urso. Em Portugal, o pinhal marcou o início da plantação intensiva de monocultura do pinheiro bravo. Foi D. Afonso III, no século XIII, que deu início à plantação dos pinheiros, sobretudo por pinheiro-manso. Contudo, foi D. Diniz que intensificou a cultura. Nos séculos XV e XVI, no contexto dos descobrimentos marítimos, o pinhal forneceu a madeira necessária para ser usada para a construção das embarcações. O pez (alcatrão vegetal extraído dos pinheiros) ajudou na proteção das caravelas.

${ }^{80}$ Ofício de Manuel Ferreira da Câmara sobre o estado atual da mata do Pinhal de Leiria. Thomar, 24/10/1798. Loc.: IHGB L. 107 Pasta 23, folha 1.
} 
sobre a administração e conservação dos bosques e arvoredos. Com a nomeação de um estudioso das ciências naturais para tal cargo, a intervenção no pinhal passou a ser fundamentada e apoiada em medidas técnicas e científicas. ${ }^{81}$

No ano de 1799, Câmara apresentou a D. Rodrigo duas importantes memórias. A primeira, datada de 20/01/1799, intitula-se Memória Sobre a Permuta de Todo o Ouro em Pó por Moeda Corrente.

Nesse estudo, Câmara alertou para a necessidade de se acabar com a circulação do ouro em pó. Para tanto, apresentou duas medidas a serem tomadas. A primeira dizia respeito ao estabelecimento na região de exploração mineira de uma Casa de Moeda, que cunhasse o produto das minas, em ouro, prata e cobre. $\mathrm{O}$ ouro, por ser um metal nobre e lucrativo para a Coroa portuguesa, por sugestão do autor deveria ser cunhado no Reino e transportado para lá em barras.

A segunda medida a ser posta em prática dizia respeito ao estabelecimento de casas em que se resgatasse ou permutasse o ouro em pó por moeda corrente. Exigia de D. Rodrigo que colocasse de forma imediata uma Casa de Fundição em funcionamento, a qual "cunhando em grande parte, ouro sobejará". ${ }^{2}$

A segunda dissertação, datada de 23/01/1799, intitula-se Memória Sobre os Meios de Obter o Cobre Necessário à Cunhagem das Moedas Destinadas aos Nossos Estabelecimentos Americanos, e Particularmente Para a Projetada Permuta de Todo o Ouro em Pó por Moeda Corrente. Câmara iniciou o estudo apresentando informações sobre a exploração das minas de cobre na Europa, mencionando as possibilidades futuras dos países que possuíam "tão útil e necessário metal". Destacou a Inglaterra, a "pátria e o mercado principal do cobre", tanto pela sua auto-suficiência, como pela sua capacidade de suprir as

\footnotetext{
${ }^{81}$ O Alvará de 30/01/1802 definiu a competência do Intendente Geral das Minas e Metais do Reino. Naquele definiu-se que o Intendente além de administrar as minas, também ficaria encarregado de administrar os bosques e matos. Por sua vez, pela Carta Régia de 01/07/ 1802, Bonifácio foi arregimentado para assumir a direção das sementeiras e plantações nos areais das costas portuguesas. Ver: VARELA, op. cit.

${ }^{82}$ CÂMARA, Manuel Ferreira da. "Memória Sobre a Necessidade de se Permutar Ouro em Pó por Moeda Corrente. Buenos Aires, 20/01/1799”. In: MENDONÇA, Marcos Carneiro. O Intendente Câmara. op . cit., p.78. De acordo com Marcos Carneiro de Mendonça, baseado em informações do professor Américo Jacobina Lacombe, informou que a menção a Buenos Aires não significa a capital da Argentina, mas um bairro de Lisboa. Conferir MENDONÇA, op. cit., p. 75.
} 
necessidades de todos aqueles que não tinham tal material. Comentou também sobre a exploração do cobre em países como a França, a Holanda, a Prússia, a Irlanda, a Suécia e a Escócia, entre outros, deixando transparecer toda a experiência e os conhecimentos que o estudioso adquirira durante a viagem realizada por diversos países da Europa Central e Setentrional.

A seguir, passou a fazer uma reflexão sobre a forma como os portugueses deveriam encontrar o cobre, numa conjuntura marcada pela crise de produção de ouro e diamantes nas regiões mineiras tradicionais - Minas Gerais, Goiás e Mato Grosso - e pelas tentativas do Estado português no sentido de não somente aumentar a produção dessas "pedras preciosas", mas também de diversificar a produção mineral para atender a demandas internas ligadas ao contexto mais amplo da Revolução Industrial. ${ }^{83}$ Portugal, não tendo cobre, tinha de importálo já cortado e preparado, sobretudo da Inglaterra e de Hamburgo, para cunhar moedas, tendo assim perdas imensas em sua balança comercial. Além disso, Câmara criticou precisamente a produção da moeda de cobre em território luso, em termos do seu custo: "A té agora a moeda de cobre tem custado, a bem dizer, tanto quanto representa, e as razões são claras. Portugal não tem cobre, recebeo já cortado e preparado para o cunho, de Hamburgo e da Inglaterra”, e sugere como solução técnica para o problema da cunhagem "o sistema de Bolthon, que tem provado ser o mais vantajoso para o cunho de moedas de pouco valor, pela facilidade com que se consegue laminar e cunhar o cobre debaixo de um só testo". Na opinião de Câmara, o custo da produção da moeda de cobre reduzia-se com a introdução dos laminadores, que ele considerava de uso vantajoso também para o ouro e para a prata; segundo Câmara, todos esses metais ainda se laminavam a braços. ${ }^{84}$

Segundo Isabel Cruz, ${ }^{85}$ no ano de 1800 a moeda de cobre - considerada de fabricação dispendiosa - escasseava em Portugal, o que constituía um problema:

\footnotetext{
${ }^{83}$ FIGUEIRÔA, Silvia Fernanda de M. et al. Aspectos Mineralógicos das "Viagens Filosóficas" Pelo Território Brasileiro na Transição do Século XVIII Para o Século XIX. História, Ciências, Saúde - Manguinhos. Rio de Janeiro, vol.11, n.3, setembro-dezembro de 2004, p.726. ${ }^{84}$ CÂMARA, Manuel Ferreira da. "Memória Sobre os Meios de Obter o Cobre Necessário à Cunhagem das Moedas Destinadas aos Nossos Estabelecimentos Americanos, e Particularmente Para a Projetada Permuta de Todo o Ouro em Pó por Moeda Corrente”. Buenos Aires, 23/01/1799. In: MENDONÇA, Marcos Carneiro. "O Intendente Câmara”. op. cit., p.312.

${ }^{85}$ CRUZ, Isabel. "Das Vantagens de Não Ser Precioso: Aspectos da Exploração e Uso do Cobre em Portugal (1789-1889)". In: http:www.triplov.com (acessado no dia 21/08/2006).
} 
apesar de cara, essa moeda era muito necessária, por ser usada "para as compras das coisas miúdas". Por esse motivo, o valor da moeda respectiva encontrava-se desfasado do preço do metal. O príncipe regente, diante do fato de o preço do metal estar sempre ascendente, ordenou que se cunhassem novas moedas de cobre de vinte, dez, cinco e três réis, para circular no reino, em substituição às anteriores, com cessação do curso da moeda antiga, no prazo máximo de dois meses

Ainda seguindo a historiadora portuguesa Isabel Cruz, a análise e as sugestões feitas por Ferreira da Câmara, devem ter encontrado eco junto ao seu interlocutor, D. Rodrigo de Sousa Coutinho, pois o setor foi um daqueles sobre os quais incidiram as iniciativas de reforma de D. Rodrigo na Casa da Moeda, na época e também quando ele assumiu o ministério da Fazenda e a presidência do Real Erário, no período de 1801 a 1803.

Câmara assinalou a importância de se olhar atentamente para as "minas, que o acaso e a natureza liberal nos têm feito conhecer no Brasil", mas que até aquele momento não tinham sido objeto de investimento e exploração do Estado português. $\mathrm{O}$ autor mencionou as minas da capitania da Bahia, região em que o Estado português tinha os olhos voltados apenas para os engenhos de açúcar. De acordo com o estudioso, nos "recôncavos da Bahia" estavam localizadas as minas mais ricas de cobre, porém nunca exploradas. Inúmeras pistas atestavam a presença do material na região, como o caso de um pedaço de cobre ali encontrado, mas que só servia "de ornamento no Real Gabinete da Ajuda" ${ }^{86} \mathrm{O}$ estudioso mencionou também as "minas da Serra da Borracha, na comarca de Minas Novas" como local que prometia a presença do mineral. Tais minas não deveriam ser exploradas por particulares, uma vez que nas mãos destes "por algum tempo

\footnotetext{
${ }^{86}$ Em 1782, foi descoberto no Brasil, Freguesia da Cachoeira, Estado da Bahia, um bloco de cobre nativo ( $97 \%$ de cobre), o maior que se conhece em toda a Europa (1200 Kg). Esse bloco foi posto pelo ministro da Marinha e Ultramar, Martinho de Mello e Castro, no Real Museu, pertencendo atualmente ao Museu de História Natural. Mas os dados antigos sobre o bloco são contraditórios, em particular acerca da origem (local e data) e também do seu peso. Tendo em vista o esclarecimento dos fatos que levaram à ocultação da verdadeira origem do bloco e à fabulação acerca das suas características, a historiadora das ciências Estela Guedes vem tomando várias iniciativas, entre as quais, interrogar os cientistas sobre o modo de conhecer o valor exato do seu peso e a sua verdadeira composição. GUEDES, Maria Estela. "Martinho de Mello e Castro e as Riquezas Naturais". In: http://triplov.com/coloquio 02/ cobre/estela.htm. (Acessado em 21/08/2006).
} 
florescem, arruínam e decaem logo", mas administradas única e exclusivamente pelo Estado português, gerando lucros e vantagens para o Soberano.

No final da carta, Câmara deixa transparecer todo o seu engajamento com o projeto político-reformista do ministro $\mathrm{D}$. Rodrigo, ao sublinhar as medidas tomadas por este com o intuito de aproveitar da melhor forma possível as "vantagens que podemos esperar das nossas colônias, que confiadas à administração de Vossa Excelência [D.Rodrigo de Sousa Coutinho] já devem esperar maior número do que têm tido". ${ }^{87}$

No projeto reformista de D. Rodrigo foi apresentada uma nova proposta de administração das possessões coloniais. A metrópole passava a ser o pólo dinamizador das relações comerciais, não mais o centro dominador e monopolizador, enquanto as possessões coloniais passariam a ser as "províncias da Monarquia", embora permanecessem sem autonomia. D. Rodrigo reelaborava o princípio da dependência econômica de cada domínio em relação à metrópole sob a máscara da interdependência e da reciprocidade nas relações entre metropolitanos e coloniais, e o da unidade política entre as partes indistintas do mundo português. Em outras palavras, a mesma prática colonialista, reinterpretada e apresentada sob novas roupagens. ${ }^{88}$

As "províncias da América que se denominam com o genérico nome de Brasil" ganhavam uma posição de destaque pela sua posição geográfica estratégica e por suas riquezas naturais, contribuindo para a formação de um grande Estado atlântico, um novo e promissor Império Luso-americano. E os ilustrados nascidos no espaço colonial desempenhariam um papel de relevância na tarefa de pensar a regeneração do Império e planejar, conjuntamente com os dirigentes metropolitanos, o seu desenvolvimento pleno e integrado do mesmo.

Manuel Serrano Pinto ${ }^{89}$ informou ainda que Câmara foi incumbido de dar consultoria ao governo português sobre os meios de obtenção de ferro para a

\footnotetext{
${ }^{87}$ CÂMARA, Manuel Ferreira da. "Memória Sobre os Meios de Obter o Cobre Necessário à Cunhagem das Moedas Destinadas aos Nossos Estabelecimentos Americanos, e Particularmente Para a Projetada Permuta de Todo o Ouro em Pó por Moeda Corrente. Buenos Aires, 23/ 01/1799”. In: MENDONÇA, Marcos Carneiro. O Intendente Câmara. op. cit., p.314.

${ }^{88}$ LYRA, op. cit.

${ }^{89}$ PINTO, Manuel Serrano. “A experiência européia de Manoel Ferreira da Câmara e seus reflexos no Brasil - algumas notas”. In: FIGUEIRÔA, S. F. de M. \& LOPES, M. M. (orgs.). Geological Sciences in Latin America. Scientifics relations and exchanges. Campinas, SP: UNICAMP/IG, 1994, p.259.
} 
fabricação de armas e sobre o projeto de restabelecimento das ferrarias de Portugal, em especial a de Figueiró dos Vinhos.

Câmara e Bonifácio foram arregimentados por D. Rodrigo para assumir postos importantes no âmbito da administração central do Império Português, para a aplicação firme e eficiente da sua política reformista. Bonifácio foi nomeado Intendente Geral das Minas e Metais do Reino, órgão estatal que seria responsável pela política de pesquisa e exploração dos recursos minerais em Portugal. Por sua vez, Manuel Ferreira da Câmara seria enviado para a América Portuguesa, mais precisamente para a região de Minas Gerais, para desempenhar a função de Intendente Geral das Minas na Capitania de Minas Gerais e Serro do Frio.

\section{V- Conclusão}

A análise da trajetória do processo de formação, especialização e profissionalização do naturalista Manuel Ferreira da Câmara revela a riqueza do pensamento ilustrado Luso-americano. Formado em Filosofia, com ênfase nas ciências naturais, e especialização nas "artes mineiras e metalúrgicas", foi membro ativo do centro de irradiação das "luzes" em Portugal, a Academia Real das Ciências de Lisboa. Nesse espaço, apresentou diversas memórias científicas que revelam a atualização do seu pensamento científico. As características da História Natural moderna, como o pragmatismo, o utilitarismo, o ecletismo, entre outras, estavam presentes nas suas dissertações. Além disso, observa-se a sua inserção no conjunto das práticas científicas mineralógicas no período entre o final do século XVIII e o início do XIX, tanto pelos termos que empregava, como pela sua postura teórico-metodológica que buscava descrever os minerais em seu local de ocorrência, dando ao seu trabalho um caráter nitidamente geográfico, onde o trabalho de campo adquiria papel de relevância. Portanto, o estudioso seguia os caminhos próprios de sua ciência, no estágio em que se encontrava naquele período.

Naturalista ligado aos interesses do Estado português, teve uma participação ativa no projeto reformista político-científico do governo mariano, sobretudo no que diz respeito aos assuntos de minas e metalurgia. Durante a sua trajetória de vida em Portugal, os estudos científicos e os interesses políticos caminharam lado a lado, numa íntima e inseparável associação. Ele colocou os conhecimentos científicos adquiridos no campo da História Natural, sobretudo os relacionados à mineralogia, em prol da regeneração da nação portuguesa. Membro 
de uma elite esclarecida e atualizada com o que de mais moderno se passava no restante da Europa além-Pirineus, acreditava que a ciência teria um papel fundamental para a realização concreta e efetiva do programa de reformas que visava conservar a integridade do Império Português. 